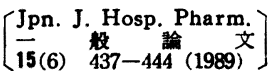

\title{
Comparison of Saliva Stimulation Methods for Noninvasive Therapeutic Drug Monitoring by Using Saliva Samples
}

\author{
YOSHIHIRO KATAGIRI, SADAO NAGASAKO, MASAKAZU HAYASHIBARA and KIKUO IWAMOTO \\ Department of Pharmacy, Shimane Medical University Hospital*
}

(Received September 29, 1989)

To find out an appropriate therapeutic drug monitoring method by using saliva, we investigated the effect of four kinds of saliva stimulation methods on salivary $\mathrm{pH}$, flow rate and composition in normal male subjects. Each of methods showed significantly different $\mathrm{pH}$, flow rate and compositions (total protein, $\mathrm{K}^{+}$and creatinine levels). It was observed that the simplest method (i.e. to move mouth and tongue) had the smallest inter-individual variation of $\mathrm{pH}$ and relatively small inter-individual variations of total protein and $\mathrm{Na}^{+}$levels. In addition, this method showed no diurnal variations of $\mathrm{pH}$, flow rate and compositions (total protein, $\mathrm{Na}^{+}$and $\mathrm{K}^{+}$levels). The present results suggest that to move mouth and tongue for salivation may be the simplest and most suitable stimulation method for therapeutic drug monitoring by using saliva samples. Furthermore, this method was found to be well applicable to a pilot study on the saliva to serum concentration ratio of mexiletine hydrochloride after the oral administration in normal subject.

Keywords-saliva stimulation method; therapeutic drug monitoring; salivary drug concentration; salivary $\mathrm{pH}$; salivary flow rate; salivary composition; mexiletine hydrochloride; human

\section{Introduction}

Utilization of salivary drug concentration for therapeutic drug monitoring meets the requirement of noninvasive and simple sample collection. It has been reported for many drugs that the salivary drug concentration is equal to the protein-unbound concentration in serum or plasma, which is regarded as the drug level related directly to the clinical effect ${ }^{1,2)}$. Since there is relatively large variation in the saliva to serum or saliva to plasma concentration ratio for many drugs, the practical application of the salivary drug concentration to the therapeutic monitoring in place of serum or plasma is very limited ${ }^{1-3)}$. It has been reported that saliva to serum drug concentration ratio is

* 出雲市塩冶町89-1; 89-1, Enya-cho, Izumo-shi, 693 Japan 
influenced by some factors such as salivary $\mathrm{pH}$, flow rate and drug protein binding as well as serum protein binding of the drug ${ }^{3-6)}$. Furthermore, these factors and composition of saliva have been known to be influenced by the method to stimulate salivation $7-9$ ).

The present study was, therefore, designed to compare the effects of four different stimulation methods for salivation on the $\mathrm{pH}$; flow rate and compositions (i.e. total protein, $\mathrm{Na}^{+}, \mathrm{K}^{+}, \mathrm{Cl}^{-}$, creatinine levels) of mixed saliva which was collected for 5 min within the appointed one-hour. The most appropriate stimulation method among them was then tested in the diurnal variation study between $7: 30$ and 19:30. In addition, the proposed method was applied to a pilot study on the monitoring of salivary levels of mexiletine hydrochloride, a new antiarrhythmic drug with relatively narrow therapeutic range $(0.75-2.0 \mu \mathrm{g} / \mathrm{ml})^{10}$ ), in a normal subject.

\section{Experimental}

\section{Materials}

Bovine serum albumin (BSA) was purchased from Sigma Chemical Co. (St. Louis, MO, U.S.A.). Mexiletine hydrochloride (MEX) was kindly supplied by Nippon Boehringer Ingelheim Co. Ltd. (Kawanishi, Japan). All other reagents used were of analytical grade.

\section{Subjects}

The present study was carried out in 10 normal healthy male volunteers ( $35 \pm 6$ years, $64 \pm 12 \mathrm{~kg}$ ). In pilot study with $\mathrm{MEX}$, one of these volunteers ( 30 years, 68 $\mathrm{kg}$ ) was selected. The pilot study protocol was approved by the Division of the Institutional Review Board.

\section{Comparison among stimulation methods}

a) Stimulaiton and collection of saliva

Salivation was stimulated by applying the following four different methods: A) to move mouth and tongue, B) to chew Sealon film (Fuji Photo Film Co. Ltd., Tokyo, Japan), C) to smell at lemon, D) to move mouth and tongue after gustatory stimulation with a drop of $10 \%$ citric acid solution on the tongue. The pre-saliva was discarded from the mouth cavity as completely as possible. All stimulations were continued for $5 \mathrm{~min}$. In method D, the stimulant in the salivated fluid accumulated for the initial 10 sec was discarded. After stimulation, the salivated fluid (i.e. mixed saliva) accumulated in the mouth cavity was directly expectorated into a glass funnel set on polystyrene tube as completely as possible. The saliva supernatant obtained after centrifugation (3000 rpm, $10 \mathrm{~min}$ ) was frozen until analysis. Each stimulation was applied to each subject in randomized order between 18:00 and 19:00.

b) Measurement of salivary $\mathrm{pH}$ and flow rate

The saliva $\mathrm{pH}$ tends to increase gradually when exposed to the atmosphere. Therefore, the saliva $\mathrm{pH}$ was measured with the glass electrode (Horiba 6028-10T, Horiba Ltd., Kyoto, Japan) which was inserted directly into the mouth cavity immediately after the stimulation for $5 \mathrm{~min}$. The specific gravity of mixed saliva was determined according to the method of Japanese Pharmacopoeia XI, yielding the value of $1.005 \pm 0.005$. 
Therefore, the measured weight of saliva sample instead of the volume was used for the calculation of the salivary flow rate by assuming that the specific gravity is approximately 1.00 as reported previously in other papers ${ }^{5,11)}$.

c) Determination of total protein

Total protein level in mixed saliva was determined by the method of Lowry et al. ${ }^{12}$ ) using BSA as the standard.

d) Determination of $\mathrm{Na}^{+}, \mathrm{K}^{+}$and $\mathrm{Cl}^{-}$

$\mathrm{Na}^{+}$and $\mathrm{K}^{+}$levels in mixed saliva were determined by flame photometer (Jasco Flame 30, Jasco Medical Instruments Inc., Tokyo, Japan). Chloride ion level was determined by chloride counter (Hiranuma CL-5, Hiranuma Sangyo Co. Ltd., Mito, Japan).

e) Determination of creatinine

Creatinine level in mixed saliva was determined by the method of Bonsnes et al ${ }^{13}$ ).

\section{Diurnal variation study}

The diurnal variations of $\mathrm{pH}$, flow rate and composition of mixed saliva collected by using method A were investigated. Saliva samples were collected at 90-min intervals between $7: 30$ and 19:30. The subjects took the same standardized meals, breakfast (758 Kcal) at $8: 15$ and lunch ( $827 \mathrm{Kcal})$ at $12: 45$, and were allowed to drink water freely during the experimental period.

\section{Pilot study with MEX}

Single dose study was carried out in one subject who received $200 \mathrm{mg}$ of MEX capsule (Mexitil ${ }^{\oplus}$ ) orally at $8: 15$ with about $200 \mathrm{ml}$ of water. Blood and saliva samples were collected at $1,2,3,4,6,8,12$ and $24 \mathrm{~h}$ after administration. The meal was taken at 7:30, 12:30 and 19:00. Periodical blood sample $(5 \mathrm{ml})$ was withdrawn from cephalic vein at the mid-point of the corresponding period of saliva collection. Saliva was collected for 5 min by using the stimulation method $A$. The concentrations of MEX in serum (total and free) and saliva samples were determined by high-performance liquid chromatography according to Grech-Bélanger et $\mathrm{al}^{14)}$. Serum free fraction was obtained by ultracentrifugation of the serum sample with Centrisart I (Sartorius GmbH, Göttingen, W. Germany).

\section{Results}

\section{Comparison among stimulation methods}

Comparisons of $\mathrm{pH}$, flow rate and composition of mixed saliva obtained by four different stimulation methods are summarized in Table 1. Method A tended to give the lowest $\mathrm{pH}$ and the smallest flow rate. In contrast, method $\mathrm{B}$ yielded the highest $\mathrm{pH}$ and the largest flow rate. It was observed that the $\mathrm{pH}$ tended to be dependent on the flow rate. Method C, which is olfactory and visual stimulaiton method, exhibited the lowest levels of total protein and creatinine among methods.

The results of analysis of variance for these four stimulation methods presented in Table 1 are shown in Table 2. Each of $\mathrm{pH}$, flow rate, total protein, $\mathrm{K}^{+}$and creatinine levels was significantly different among four methods.

Table 3 represents inter-individual variations of $\mathrm{pH}$, flow rate and composition of 
mixed saliva collected by using four methods. It was observed that the simplest method, $A$, had the smallest inter-individual variation of $\mathrm{pH}$ and relatively small inter-individual variations of total protein and $\mathrm{Na}^{+}$levels. On the other hand, method $\mathrm{C}$ yielded the largest inter-individual variations of $\mathrm{pH}$, flow rate, $\mathrm{Na}^{+}$and $\mathrm{Cl}^{-}$levels. Therefore, method A was employed as a candidate method hereafter. All methods had larger interindividual variations of $\mathrm{Na}^{+}$and $\mathrm{Cl}^{-}$levels than that of $\mathrm{K}^{+}$level.

\section{Diurnal variation study}

Fig.1 and 2 show the diurnal time-course of $\mathrm{pH}$, flow rate and composition of mixed saliva collected by method $A$ between $7: 30$ and 19:30. Only salivary pH seemed to have a tendency to rise very gradually with the flow rate. Table 4 shows the results of analysis of variance for these 9 collection time-points summarized previously in Fig.1 and 2 . The diurnal variations of $\mathrm{pH}$, flow rate, total protein, $\mathrm{Na}^{+}$and $\mathrm{K}^{+}$levels were not observed at all. Each of $\mathrm{pH}$, flow rate and composition of mixed saliva was also compared between preand post-meal times. There was no significant difference between them.

\section{Pilot study with MEX}

The serum and saliva levels of MEX after the single oral dose in one subject are shown in Fig.3. Saliva MEX level was always higher than the serum level. Time-course of the salivary drug level was found to be almost parallel with that of the serum total or free level. Any time-lag between both peaks in serum and saliva were not observed. In regression analysis for saliva against serum MEX levels at post-absorption phase (4-24h), a good correlation between saliva and serum drug levels was obtained (serum total; $r=0.986, p<0.001$ : serum free; $r=0.986, p<0.01$ ). Accordingly, it was found that saliva to serum MEX concentration ratio was almost constant in this subject at $4-24 \mathrm{~h}$ after the dosage (serum total; $3.7 \pm 0.4$ : serum free; $10.0 \pm 0.7$ ).

\section{Discussion}

It has been reported that salivary stimulation method may modulate significantly salivary $\mathrm{pH}$, flow rate and composition and subsequently modify the saliva to serum or saliva to plasma drug concentration ratio ${ }^{3-6)}$. Therefore, more fundamental investigation for the effect of stimulation methods on salivary $\mathrm{pH}$, flow rate and composition is required before saliva samples are used efficiently instead of blood samples for drug monitoring. In the first place of the present study, effect of four stimulation methods on $\mathrm{pH}$, flow rate and composition of mixed saliva collected within the appointed one-hour was examined in detail.

Each of $\mathrm{pH}$, flow rate and composition (total protein, $\mathrm{K}^{+}$and creatinine levels) of the mixed saliva was significantly different among methods. The analysis of variance for these four stimulation methods suggested the possibility that drug concentration in mixed saliva might be influenced by stimulation method. Namely, stimulation method itself would be of substantial importance for the variation of the saliva to serum (or saliva to plasma) drug concentration ratios.

It has been reported that the reliable use of salivary concentration data in the therapeutic drug monitoring may be dependent on the magnitude of the inter-individual 
Table 1. pH, Flow Rate and Composition of Mixed Saliva by Four Stimulation Methods

\begin{tabular}{|c|c|c|c|c|c|c|c|}
\hline $\begin{array}{l}\text { Stimulation } \\
\text { Method }\end{array}$ & pH & $\begin{array}{c}\text { Flow } \\
\text { Rate } \\
\text { (ml/min) }\end{array}$ & $\begin{array}{l}\text { Total } \\
\text { Protein } \\
(\mathrm{mg} / \mathrm{ml})\end{array}$ & $\underset{(m \mathrm{Eq} / \mathrm{l})}{\mathrm{Na}^{+}}$ & $\begin{array}{c}\mathrm{k}^{+} \\
(\mathrm{mEq} / 1)\end{array}$ & $\underset{(\mathrm{mEg} / 1)}{\mathrm{Cl}^{-}}$ & $\begin{array}{l}\text { Creatinine } \\
\text { (mg/di) }\end{array}$ \\
\hline $\mathbf{A}$ & $\begin{array}{l}6.65 \\
\pm 0.19\end{array}$ & $\begin{array}{l}0.51 \\
\pm 0.17\end{array}$ & $\begin{array}{l}3.51 \\
\pm 0.74\end{array}$ & $\begin{array}{r}7.5 \\
\pm \quad 3.2\end{array}$ & $\begin{array}{r}20.2 \\
\pm 2.7\end{array}$ & $\begin{array}{l}13.7 \\
\pm \quad 2.3\end{array}$ & $\begin{array}{c}0.31 \\
\pm 0.06\end{array}$ \\
\hline $\mathbf{B}$ & $\begin{array}{r}7.01 \\
\pm 0.21\end{array}$ & $\begin{array}{l}1.43 \\
\pm 0.49\end{array}$ & $\begin{array}{r}2.82 \\
\pm 0.84\end{array}$ & $\begin{array}{l}24.0 \\
\pm 18.2\end{array}$ & $\begin{array}{l}19.3 \\
\pm 2.1\end{array}$ & $\begin{array}{l}21.4 \\
\pm \quad 9.4\end{array}$ & $\begin{array}{l}0.27 \\
\pm 0.05\end{array}$ \\
\hline C & $\begin{array}{c}6.92 \\
\pm 0.24\end{array}$ & $\begin{array}{l}1.31 \\
\pm 0.76\end{array}$ & $\begin{array}{l}1.96 \\
\pm 0.49\end{array}$ & $\begin{array}{l}13.9 \\
\pm 13.8\end{array}$ & $\begin{array}{r}16.6 \\
\pm 2.2\end{array}$ & $\begin{array}{l}13.5 \\
\pm 10.0\end{array}$ & $\begin{array}{l}0.19 \\
\pm 0.03\end{array}$ \\
\hline D & $\begin{array}{r}6.73 \\
\pm 0.21\end{array}$ & $\begin{array}{l}0.85 \\
\pm 0.27\end{array}$ & $\begin{array}{r}2.32 \\
\pm 0.46\end{array}$ & $\begin{array}{l}16.3 \\
\pm 11.8\end{array}$ & $\begin{array}{r}19.4 \\
\pm 1.9\end{array}$ & $\begin{array}{l}16.8 \\
\pm \quad 7.6\end{array}$ & $\begin{array}{l}0.40 \\
\pm 0.05\end{array}$ \\
\hline
\end{tabular}

Each value represents the mean \pm S.D. of 10 subjects.

$A$ : Nove wouth and tongue.

B: Chew Sealon film.

$C$ : Snell at lemon

D: Hove mouth and tongue after gustatory stimulation with a drop of citric acid solution.

Table 2. Analysis of Variance for Four Stimulation Methods

\begin{tabular}{|c|c|c|c|c|c|}
\hline \multirow[b]{2}{*}{. } & \multicolumn{2}{|c|}{ Sum of Squares } & \multicolumn{2}{|c|}{ Mean Squares } & \multirow{2}{*}{ F-Ratio } \\
\hline & among & within & among & within & \\
\hline pH & 0.84 & 1.63 & 0.28 & 0.05 & $6.15^{a)}$ \\
\hline Flow Rate & 5.39 & 8.37 & 1.80 & 0.23 & $7.73^{a)}$ \\
\hline Total Protein & 13.52 & 15.33 & 4.51 & 0.43 & $10.58^{a)}$ \\
\hline $\mathrm{Na}^{+}$ & 1394.28 & 6033.50 & 464.76 & 167.60 & 2.77 \\
\hline $\mathrm{K}^{+}$ & 74.53 & 186.31 & 24.84 & 5.18 & $4.80^{a)}$ \\
\hline $\mathrm{Cl}^{-}$ & 406.33 & 2274.95 & 135.44 & 63.19 & 2.14 \\
\hline Creatinine & 0.24 & 0.09 & 0.08 & 0.003 & $31.25^{a)}$ \\
\hline
\end{tabular}

Degree of freedom is 3,36 .

a) Significant at $p<0.01$.

Table 3. Inter-Individual Variation in $\mathrm{pH}$, Flow Rate and Composition of Mixed Saliva by Four Stimulation Methods

\begin{tabular}{|c|c|c|c|c|c|c|c|}
\hline \multirow{2}{*}{$\begin{array}{l}\text { Stimulation } \\
\text { Method }\end{array}$} & \multicolumn{7}{|c|}{ Coefficient of Variation $(*)$} \\
\hline & pH & $\begin{array}{l}\text { Plow } \\
\text { Rate }\end{array}$ & $\begin{array}{c}\text { Total } \\
\text { Protein }\end{array}$ & $\mathrm{Na}^{+}$ & $\mathbf{R}^{+}$ & $\mathrm{Cl}^{-}$ & Creatinine \\
\hline $\mathbf{A}$ & 2.9 & 33.3 & 21.1 & 42.7 & 13.4 & 16.8 & 19.4 \\
\hline $\mathbf{B}$ & 3.0 & 34.8 & 29.8 & 75.8 & 10.9 & 43.9 & 18.5 \\
\hline $\mathbf{C}$ & 3.5 & 58.0 & 25.0 & 99.3 & 13.3 & 74.1 & 15.8 \\
\hline D & 3.1 & 31.8 & 19.8 & 72.4 & 9.8 & 45.2 & 12.5 \\
\hline
\end{tabular}

A: Hove wouth and tongue.

B: Chew Sealon film.

C: seell at lewon.

D: Nove mouth and tongue after gustatory stimulation with a drop of citric acid solution, 

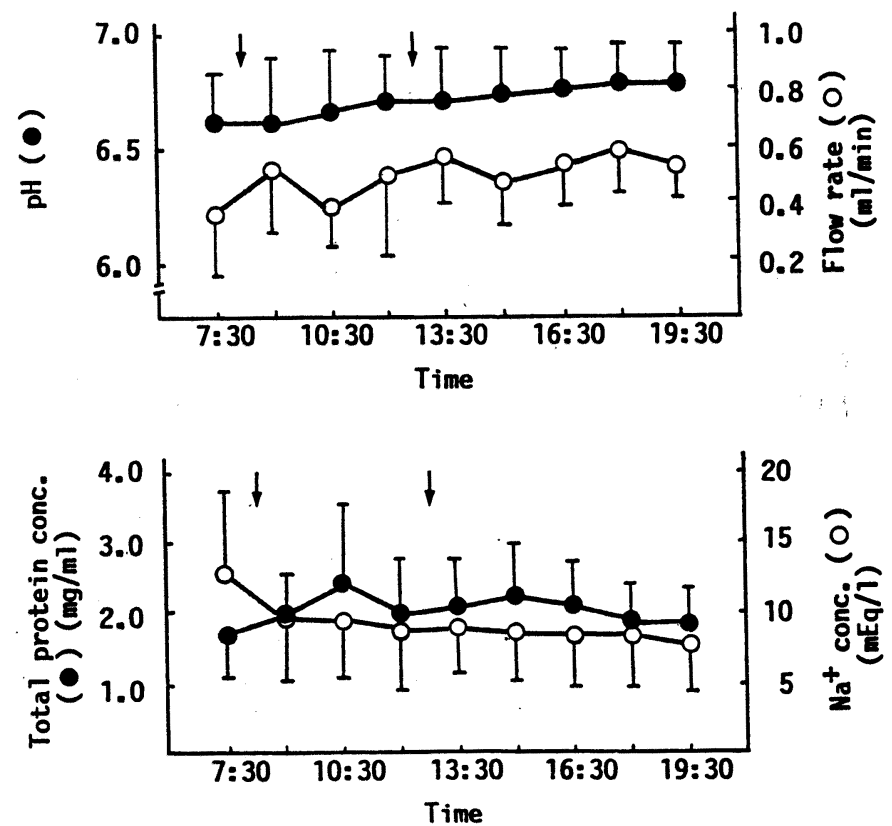

Fig. 1. Diurnal Variation of $\mathrm{pH}$, Flow Rate, Total Protein and $\mathrm{Na}^{+}$in Mixed Saliva

Each point and vertical bar represent the mean and S.D. of 10 subjects. Arrow indicates the time of breakfast and lunch. Salivation was stimulated by method A.
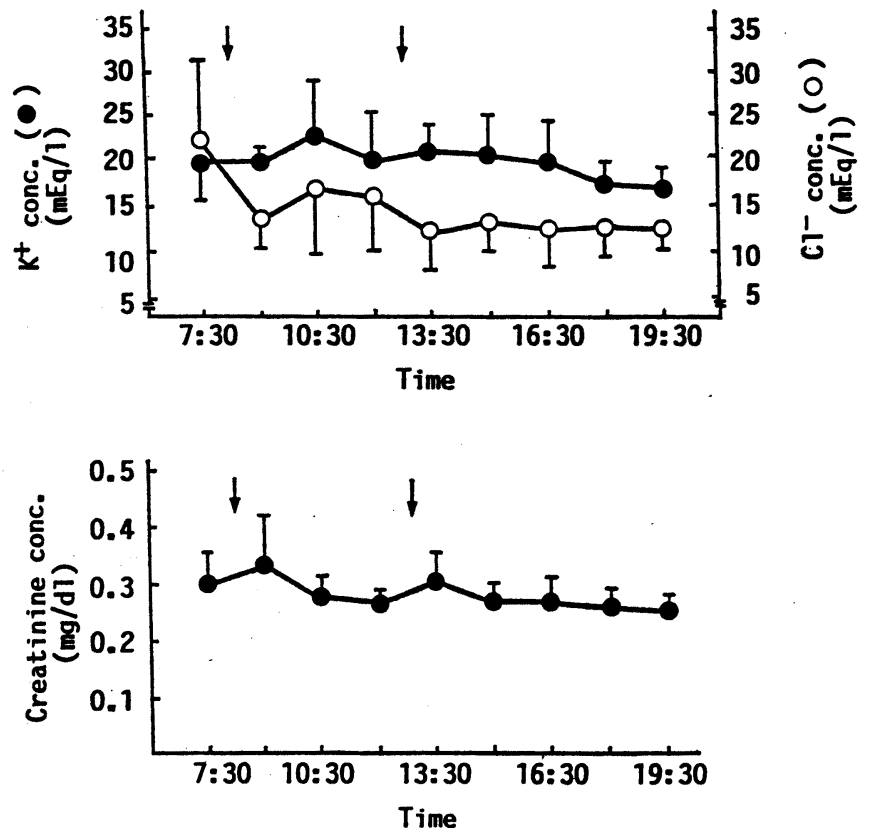

Fig. 2. Diurnal Variation of $\mathrm{K}^{+}, \mathrm{Cl}^{-}$and Creatinine in Mixed Saliva Each point and vertical bar represent the mean and S.D. of 10 subjects except creatinine ( 7 subjects). Arrow indicates the time of breakfast and lunch. Salivation was stimulated by method $\mathrm{A}$. 
Table 4. Analysis of Variance for Nine Collection Times

\begin{tabular}{|c|c|c|c|c|c|}
\hline & \multicolumn{2}{|c|}{ Sum of Squares } & \multicolumn{2}{|c|}{ Mean Squares } & \multirow{2}{*}{ F-Ratio } \\
\hline & among & within & among & within & \\
\hline pH & 0.33 & 3.98 & 0.04 & 0.05 & 0.85 \\
\hline Flow Rate & 0.48 & 2.86 & 0.06 & 0.04 & 1.71 \\
\hline Total Protein & 4.17 & 47.52 & 0.52 & 0.59 & 0.89 \\
\hline $\mathrm{Na}^{+}$ & 174.51 & 1524.35 & 21.81 & 18.82 & 1.16 \\
\hline $\mathrm{R}^{+}$ & 191.04 & 1353.54 & 23.88 & 16.71 & 1.43 \\
\hline $\mathrm{Cl}^{-}$ & 761.02 & 2639.10 & 95.13 & 32.58 & $2.92^{a)}$ \\
\hline Creatinine & 0.04 & 0.13 & 0.005 & 0.002 & $2.14^{b)}$ \\
\hline
\end{tabular}

Salivation was stimulated by method $A$.

Degree of freedom is 8,81 except creatinine $(8,54)$.

a) Significant at $p \times 0.01$.

b) Significant at $p \times 0.05$.

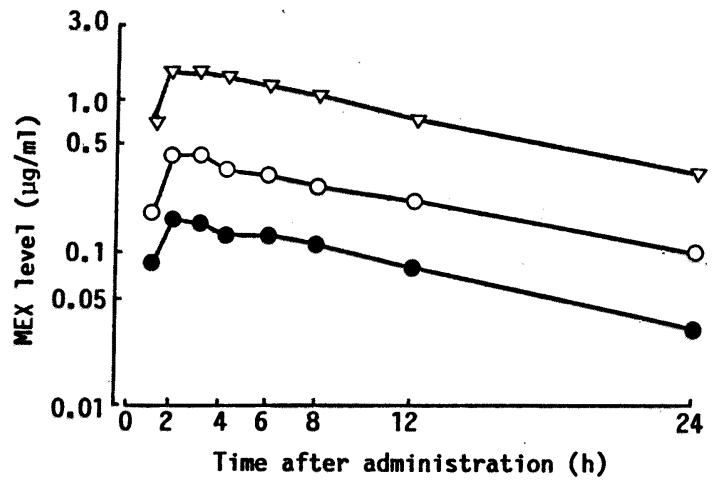

Fig. 3. Serum and Saliva Levels of MEX after Single Oral Administration in One Subject

Dose: $200 \mathrm{mg}$ as MEX. Saliva stimulation: method A.

Key: $O$, serum total; $\bullet$, serum free; $\nabla$, saliva

variation in the saliva to serum (or plasma) concentration ratio values ${ }^{1-3}$ ). Larger interindividual variations of salivary $\mathrm{pH}$, flow rate and composition may produce larger interindividual variation of saliva to serum (or plasma) drug concentration ratios. Among them, salivary $\mathrm{pH}$ is one of the most important determining factors for the salivary concentration of ionizable drugs according to Matin's equation based on the $\mathrm{pH}$-partition hypothesis ${ }^{15)}$. Salivary protein level might be another important factor. As shown in Table 3, method A yielded the smallest inter-individual variation of $\mathrm{pH}$ and relatively small inter-individual variations of total protein and $\mathrm{Na}^{+}$levels. Therefore, it was proposed that method $\mathrm{A}$ might be the most useful method to stimulate salivation among the present four methods and this method was employed thereafter.

Dawes has reported that unstimulated whole saliva (i.e. mixed saliva) and stimulated parotid saliva showed significant circadian rhythm either in the flow rate or in the compositions (protein, $\mathrm{Na}^{+}$and $\mathrm{K}^{+}$and $\mathrm{Cl}^{-}$levels) ${ }^{16)}$. As regards method $\mathrm{A}$, we then investigated the diurnal variation of these factors. The diurnal variations of $\mathrm{pH}$, flow rate and major components (total protein, $\mathrm{Na}^{+}$and $\mathrm{K}^{+}$levels) was not observed at all. These 
results suggest that method A for salivation may be the simplest and most suitable method for therapeutic drug monitoring by using saliva samples.

Therapeutic monitoring of serum (or plasma) MEX levels has been required due to relatively narrow therapeutic range of this drug ${ }^{10)}$. Beckett and Chidomere ${ }^{17)}$ have reported that the salivary concentration of MEX is higher than the corresponding plasma concentration. The results in the present pilot study were consistent with those by Beckett and Chidomere and showed almost constant ratio of saliva to serum MEX levels over the wide concentration range. As is obvious from the present results, method A was thought to be well applicable to the fundamental studies on the saliva to serum concentration ratio of MEX.

In conclusion, to move mouth and tongue was the most suitable method to stimulate salivation for use of the saliva as a biological sample. Furthermore, this method was found to be useful for the detailed investigation to predict or estimate serum MEX level from the salivary level.

\section{References}

1) M. Danhof, and D.D. Breimer, Clin. Pharmacokinet., 3; 39-57 (1978).

2) G.G. Graham, "Pharmacokinetics: Theory and Methodology", eds. by M. Rowland, and G. Tucker, Pergamon Press, Elmsford, 1986, pp. 421-437.

3) J.C. Mucklow, M.R. Bending, G.C. Kahn, and C.T. Dollery, Clin. Pharmacol. Ther., 24, 563-570 (1978).

4) C.P. Dawes, M.J. Kendall, and V.A. John, Br. J. Clin. Pharmacol., 5, 217-221 (1978).

5) J. Watanabe, Y. Nakase, Y. Urasaki, Y. Hayashi, K. Iwamoto, and S. Ozeki, J. Pharmacobio-Dyn., 4, 968-971 (1981).

6) J. Watanabe, Y. Urasaki, Y. Nakase, H. Ueda, K. Iwamoto, and S. Ozeki, J. Pharmacobio-Dyn., 4, 336-344 (1981).

7) C. Dawes, and G.N. Jenkins, J. Physiol., 170, 86-100 (1964).

8) I.L. Shannon, J. Den. Res., 52, 1157 (1973).

9) G.N. Jenkins, "The physiology and biochemistry of the mouth", Blackwell, Oxford, 1978, pp. 284-359.

10) N.P.S. Campbell, J.G. Kelly, A.A.J. Adgey, and R.G. Shanks, Br. J. Clin. Pharmacol., 6, 103-108 (1978).

11) J. Watanabe, Y. Hayashi, K. Iwamoto, and S. Ozeki, Chem. Pharm. Bull., 33, 1187-1194 (1985).

12) O.H. Lowry, N.J. Rosebrough, A.L. Farr, and R.J. Randall, J. Biol. Chem., 193, 265275 (1951).

13) R.W. Bonsnes, and H.H. Taussky, J. Biol. Chem., 158, 581-591 (1945).

14) O. Grech-Bélanger, J. Turgeon, and M. Gilbert, J. Chromatogr. Sci., 22, 490-492 (1984).

15) S.B. Matin, S.H. Wan, and J.H. Karam, Clin. Pharmacol. Ther., 16, 1052-1058 (1974).

16) C. Dawes, J. Physiol., 220, 529-545 (1972).

17) A.H. Beckett, and E.C. Chidomere, Postgrad. Med. J., 53 (Suppl. 1), 60-66 (1977). 